\title{
RELATIONSHIP BETWEEN FERTILIN B MRNA EXPRESSION AND THE FERTILIZING POTENTIALS OF HUMAN SPERMATOZOA
}

\author{
Adel A. Zalata ${ }^{1}$, Amany Atwa ${ }^{1}$, Naglaa Mokhtar', Mohamed khaled ${ }^{2}$ \\ MEDICAL BIOCHEMISTRY DEPARTMENT ${ }^{l}$, DEPARTMENT OF \\ DERMATOLOGY, VENEROLOGY \& ANDROLOGY ${ }^{2}$, \\ FACULTY OF MEDICINE, MANSOURA UNIVERSITY, EGYPT
}

Received 8/5/2016-Accepted 1/8/2016

\begin{abstract}
Fertilin is a sperm surface protein that belongs to the ADAM (a disintigrin and a metalloproteinase) family of integral membrane proteins. It mediates adhesion and fusion between the sperm and egg plasma membranes that may play important roles in mammalian fertilization. This study aimed to explore the relation between fertilization ability of human sperm and fertilin $\beta$ mRNA expression in non-fertile men. Expression of fertilin $\beta$ gene mRNA was determined by RT-PCR from 141 semen samples (infertile $n=81$ and normal fertile $n=60$ men). Total RNA was extracted from sperm pellets. cDNA was generated then amplified. Computer assisted semen analysis and acrosine activity test were also performed. ELISA was done to measure $\mathrm{FSH}, \mathrm{LH}$, testosterone and prolactin. The study showed lowered sperm fertilin $\beta$ expression in infertile group together with decreased sperm motility and other sperm functions. Also, there was significant positive correlation between fertilin $\beta$ expression and testosterone levels. Furthermore, normal morphology may influence changes of fertilin $\beta$ as shown by multiple regression analysis.

From this study it can be concluded that infertility which is associated with decreased expression of sperm fertilin $\beta$ could be due to failure of sperm migration into the oviduct. Moreover, defective protease can produce incomplete fertilin $\beta$ processing with improper maturation of sperm proteins. Here in this study showed possible direct role of fertilin- $\beta$ in fertilization and also in sperm morphology and hence sperm capicitation.
\end{abstract}

* Correspondence Author (e mail: : amanyatwa@hotmail.com) 
Keywords: Fertilin $\beta$ expression, Infertility, Hormonal profile, Sperm function.

\section{INTRODUCTION}

During the process of human fertilization in vivo or in conventional in vitro fertilization (IVF), sperm must be capable of undergoing the acrosome reaction, binding to the zona pellucida ( $\mathrm{ZP})$, and penetrating the $\mathrm{ZP}$ to fuse with the oolema. The key role in this process is played by fertilin $\beta$ (Howes et al., 2001, Geraci and Giudice, 2006, Vieira and Miller 2006).

The ADAM (a disintegrin and metalloprotease) family of sperm cellsurface proteins, including fertilin $\alpha / \beta$ (ADAM1/2) and cyritestin (ADAM3), provide the motif that serves as recognition site to bind integrin a6b1 on oocytes to promote successful fusion adhesion and fusion between the sperm and egg plasma membranes (Primakoff and Myles, 2000). Moreover, ADAM7 is required for normal fertility and is important for the maintenance of epididymal integrity and for sperm morphology, motility, and membrane proteins (Choi et al., 2015).

Fertilin $\alpha$ and $\beta$ form a heterodimer and belong to the ADAM family of integral membrane proteins (Menezo, 2006). Fertilin is located in the equatorial region of the sperm and the soluble extracellular domains of fertilin $\alpha$ and fertilin $\beta$ can bind to the microvillar region of murine eggs (Bigler et al., 2000).

The human fertilin $\beta$ is synthesized as a precursor in the testis and cleaved to its mature form in the corpus epididymis (Evans, 1999). Fertilin $\beta$ is proteolyticly processed while spermatozoa are in transit through the epididymis helping in acquisition of fertilization competence in spermatozoa and exposes an epitope that has a role in sperm-egg interactions. Also it triggers relocalization of fertilin from the whole sperm head to the posterior head where this is important for successful fertilization (Wolkowicz et al., 2008).

The aim of this study was to highlight the association between fertilin $\beta$ mRNA expression and fertilization ability of human sperm as determined by sperm function. 


\section{MATERIALS AND METHODS}

A total of 141 subjects were included in the current study. Semen samples were obtained from men attending the Andrology Outpatient Clinic, Mansoura University. Informed consent was obtained from all participants. They were grouped into fertile men as control group $(n=60)$ and infertile men $(n=81)$. Infertility is defined as the inability of a sexually active, non-contracepting couple to achieve pregnancy in one year. The male partner can be evaluated for infertility or subfertility using a variety of clinical interventions, and also from a laboratory evaluation of semen." according to the recommendation of WHO (WHO, 2010). After complete liquefaction, Computer assisted semen analysis (CASA) (Autosperm Fertipro, Belguim) (Hinting et al., 1998) and acrosin activity test of spermatozoa by gelatinolysis were performed (Henkel et al., 1995). Sperm morphology was evaluated on stained smear by phase contrast microscope and Sperm Mac stain (Fertipro, Belguim) according to World Health Organization. Sil-select gradient (Autosperm Fertipro, Belguim) has been performed on the pellet to select spermatozoa only and to avoid the contamination either with spermatogenic or pus cells.

Reverse transcription-PCR for fertilin $\beta$ mRNA expression:

Semen samples were collected, and total RNA was extracted using the TriFast reagent (Peqlab, Germany) as described in the manufacturer's instructions. The purity of RNA was checked at $260 \mathrm{~nm}$ using the Nanodrop spectrophotometer, NanoPhotometer ${ }^{\circledR}$ P-Class (Implen, Germany). The absence of RNA degradation was confirmed by electrophoresis on a $1.5 \%$ agarose gel electrophoresis containing ethidium bromide. First-strand cDNA was generated by using Maxima First Strand cDNA Synthesis Kit for RT-PCR (Thermo Scientific, U.S.A) according to manufacturer's instructions. Fertilin $\beta$ and GAPDH genes were amplified using a PTC-200 thermal cycler (MJ Research, Essex, UK). Primer sequences were as follows: 
Adel A. Zalata1, Amany Atwa1et all..

\begin{tabular}{|l|l|l|l|}
\hline Primer & \multicolumn{1}{|c|}{ Sequence } & $\begin{array}{l}\text { Product } \\
\text { length } \\
\text { (bp) }\end{array}$ & Reference \\
\hline Fertilin $\beta$ & $\begin{array}{l}\text { Forward: } \\
\text { 5-AAC CAC CAA CTG CCA TTA TTC- } \\
\text { Reverse: } \\
\text { 5-TTA TTG ACC GTA TTT TCT CCG - } \\
\text { 3 }\end{array}$ & $\mathbf{1 5 5}$ & $\begin{array}{l}\text { Martynów } \\
\text { et al., } \\
\text { 2007) }\end{array}$ \\
\hline $\begin{array}{c}\text { Glyceraldehy } \\
\text { de-3- } \\
\text { phosphate } \\
\begin{array}{c}\text { Dehydrogena } \\
\text { se (GAPDH) }\end{array}\end{array}$ & $\begin{array}{l}\text { Forward: } \\
\text { 5'-AAT CCC ATC ACC ATC TTC C-3' }\end{array}$ & 382 & $\begin{array}{l}\text { Reverse: } \\
\text { 5'-CAT CAC GCC ACA GTT TCC -3' }\end{array}$ \\
\hline
\end{tabular}

The cycle profile was as follows: initial denaturation at $94^{\circ} \mathrm{C}$ for 5 minutes, followed by 40 cycles of denaturation at $94^{\circ} \mathrm{C}$ for 30 seconds, annealing at $52^{\circ} \mathrm{C}$ for 1 minute and elongation at $72^{\circ} \mathrm{C}$ for 1 minute, and a final incubation at $72{ }^{\circ} \mathrm{C}$ for 10 minutes.

The amplified RT-PCR products were electrophoresed on $2 \%$ agarose gel and DNA was visualized with ethidium bromide staining via light UV transilluminator and photographed. The results were analyzed with scion image $\mathrm{R}$ release Alpha 4.0.3.2. Software for windows which performs bands detection and conversion to peaks. Area under each peak was calculated in square pixels for quantification. Fertilin $\beta$ mRNA expression levels were determined by calculating the ratio between the square pixel values of the target bands in relation to the control bands (GAPDH, housekeeping gene for RT-PCR).

Alpha- glucosidase activity in seminal plasma was measured according to the method described by Guerin et al. (1986) to evaluate the function of the epididymis. The kit supplied from Ferti Pro N.V. (Industriepark Noord, Beerneme, Belgium).

Acrosin activity index determination was assessed by gelatin-covered slides which prepared by $5 \%$ gelatin (Merck, Darmstadt, Germany) onto microscope slides. Purified spermatozoa were smeared on the prepared slides and incubated in a moist chamber at $37^{\circ} \mathrm{C}$ for 2 hours. The halo diameter, halo formation rate and acrosin activity index were calculated (Henkel et al., 1995).

Hormonal profile including: follicle stimulating hormone (FSH), lutenizing hormone $(\mathrm{LH})$, testosterone \& prolactin were measured on sera collected from blood samples by enzyme linked immuno-sorbant assay (ELISA). 


\section{STATISTICAL ANALYSIS}

Statistical analysis was done by using MedCalcR program version 10.0.1 (Schoonjans et al., 1995).

\section{RESULTS}

Table (1) showed semen parameters in both fertile and infertile groups expressed as median and range. The present study showed decreased motility, velocity and alpha-glucosidase activity in infertile group compared with fertile group.

Table (1): Semen parameters of fertile and infertile groups (median and range)

\begin{tabular}{|c|c|c|}
\hline Parameters & Fertile $n=60$ & Infertile $n=81$ \\
\hline Volume (ml) & $4.0(2.0-7.0)$ & $4.0(1.0-9.2)$ \\
\hline Concentration (million /ml) & $70.4(44.8-96.0)$ & $\begin{array}{l}8.15 *(0.85- \\
18.84)\end{array}$ \\
\hline Grade A motility (\%) & $54.0(41.0-60.0)$ & $4.0 *(0.0-25.0)$ \\
\hline Grade A+B motility (\%) & $61.0(51.0-67.0)$ & $12.0 *(2.0-39.0)$ \\
\hline Velocity $(\mu \mathrm{m} / \mathrm{sec})$ & $79.65(63.4-86.6)$ & $36.2 *(8.8-75.5)$ \\
\hline Linear velocity $(\mu \mathrm{m} / \mathrm{Sec})$ & $62.3(42.9-70.7)$ & $20.8 *(5.7-52.6)$ \\
\hline Linearity index (\%) & $82.0(67.5-86.7)$ & $60.3 *(33.7-97.4)$ \\
\hline Normal morphology (\%) & $64.0(58.0-66.0)$ & $2.0 *(0.0-18.0)$ \\
\hline WBCs (million/ml) & $0.6(0.4-0.6)$ & $0.8(0.3-5.4)$ \\
\hline Alpha-glucosidase activity (U/ml) & $69.3(45.4-90.7)$ & $26.4 *(18.4-44.6)$ \\
\hline
\end{tabular}

$\mathrm{n}=$ number of cases

* significant at $\mathrm{P}<0.05$ comparison between the fertile and infertile groups

Analysis of variance revealed that sperm fertilin $\beta$ mRNA expression is significantly decreased in infertile samples as compared with fertile group (table 2, fig 1). Sperm function tests including Acrosin index levels, halo, and halo percent were all high statistically significant in fertile men when compared with infertile group as shown in (table 2). 
Table (2): Fertilin $\beta$ mRNA expression and acrosin activity test in the fertile and infertile groups (median-range)

\begin{tabular}{|l|l|l|}
\hline Parameters & Fertile $\mathrm{n}=60$ & Infertile $\mathrm{n}=\mathbf{8 1}$ \\
\hline Acrosin acitivity index & $12.25(8.86-19.49)$ & $\begin{array}{l}1.17^{*}(0.55- \\
9.57)\end{array}$ \\
\hline Halo diameter (nm) & $17.4(12.8-23.7)$ & $\begin{array}{l}10.3^{*}(9.0- \\
14.6)\end{array}$ \\
\hline Halo formation rate \% & $76.0(63.0-90.0)$ & $\begin{array}{l}12.0^{*}(6.0- \\
66.0)\end{array}$ \\
\hline Fertilin mRNA expression & $1.76(0.96-2.38)$ & $\begin{array}{l}\mathbf{0 . 6 1}(\mathbf{0 . 2 1}- \\
1.28)\end{array}$ \\
\hline
\end{tabular}

$\mathrm{n}=$ number of cases

* significant at $\mathrm{P}<0.05$ comparison between the fertile and infertile groups

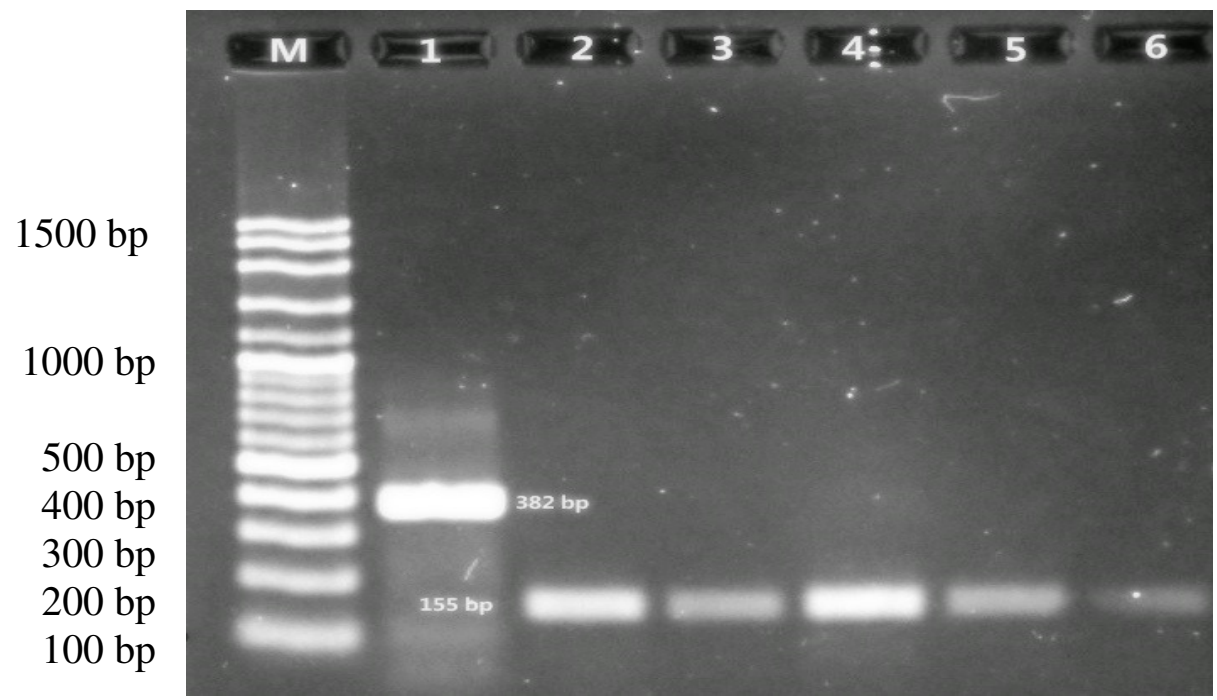

Figure 1 Expression analysis of fertilin $\beta$ mRNA from semen samples by RT-PCR. M= 100 bp DNA ladder. The upper 382 bp band represents the internal control GAPDH (lane 1); the lower 155 bp bands represent amplification of fertilin $\beta$ from fertile samples (lane $2 \& 4$ ) and infertile samples (lane 3, $5 \& 6$ ). 
However, the hormonal profile presented significant increase in FSH levels and significant decrease in testosterone levels in infertile than fertile group. While there was insignificant difference between both groups regarding LH and prolactin (table 3).

Table (3): serum hormonal levels in the fertile and the infertile groups

\begin{tabular}{|l|l|l|}
\hline \multicolumn{1}{|c|}{ Parameters } & \multicolumn{1}{|c|}{ Fertile n=60 } & \multicolumn{1}{|c|}{ Infertilen=81 } \\
\hline FSH $(\mathrm{mIU} / \mathrm{ml})$ & $6.8(3.9-9.6)$ & $10.1 *(5.2-22.0)$ \\
\hline LH $(\mathrm{mIU} / \mathrm{ml})$ & $6.4(4.5-9.3)$ & $6.4(3.0-12.4)$ \\
\hline Prolactin $(\mathrm{ng} / \mathrm{ml})$ & $5.4(3.5-8.6)$ & $6.5(2.4-12.5)$ \\
\hline Estradiol $(\mathrm{pg} / \mathrm{ml})$ & $32.0(24.0-45.0)$ & $36.0 *(20.0-123.0)$ \\
\hline Testosterone $(\mathrm{ng} / \mathrm{dl})$ & $790.0(506.0-1106)$ & $530.0 *(301.0-1200.0)$ \\
\hline
\end{tabular}

$\mathrm{n}=$ number of cases

* significant at $\mathrm{P}<0.05$ comparison between the fertile and infertile groups

Spearman rank correlation test showed that fertilin $\beta$ mRNA expression was found to be significantly positively correlated with all studied seminal parameters (concentration, normal morphology, velocity, linearity index, grade $\mathrm{A} \& \mathrm{~B}$ motility, and alpha-glucosidase $(\mathrm{p}<0.0001)$ ), sperm functions (acrosine activity index, Halo diameter, and Halo formation rate $\%,(\mathrm{p}<0.0001))$ and testosterone level $(\mathrm{r}=$ $0.493, \mathrm{p}<0.0001$ ), while there was significant negative correlation with FSH level $(r=-0.427, p<0.0001)$. 
Stepwise multiple regression analysis was done between different studied variables to detect the factors which may influence changes of fertilin $\beta$ mRNA expression, where sperm morphology was found to be the possible determinant one $(\mathrm{F}-$ ratio $=322.9$, $\mathrm{p}<0.001)$.

ROC curve analysis was done to discriminate between fertile group and infertile group using fertilin $\beta$ mRNA expression, grade $A$ motility, acrosin activity as discriminative markers (fig 2, table 4).

Table (4): ROC curve analysis of fertilin $\beta$ mRNA expression, acrosin activity index and grade $A$ motility

\begin{tabular}{|l|l|l|l|}
\hline Variable & AUC & SE & 95\% CI \\
\hline Fertilin $\beta$ mRNA expression & 0.961 & 0.0176 & 0.914 to 0.987 \\
\hline Acrosin activity index & 0.986 & 0.0111 & 0.950 to 0.999 \\
\hline Grade A motility \% & 0.991 & 0.00927 & 0.957 to 1.000 \\
\hline
\end{tabular}

AUC: Area Under Curve SE: Standard Error $\quad$ CI: Confidence Interval 


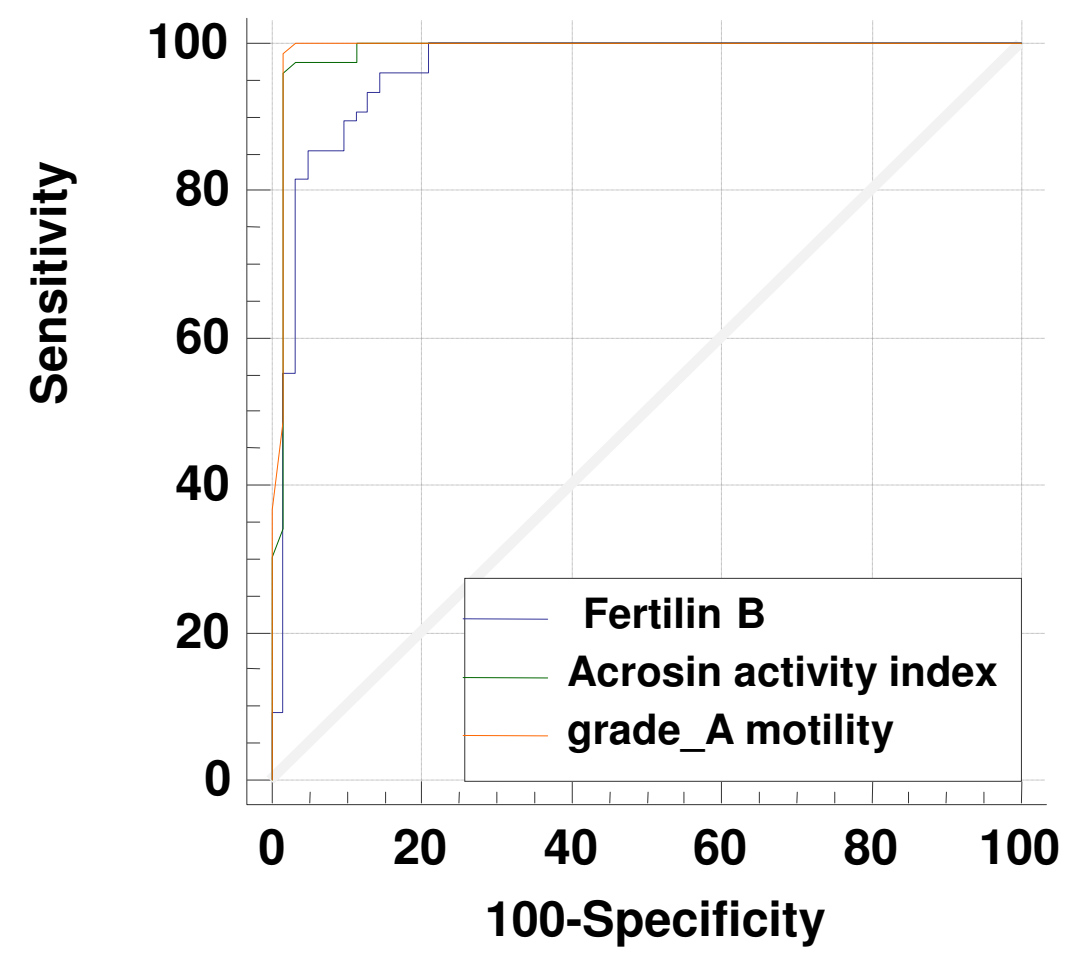

Fig 2: ROC curve analysis of fertilin $\beta$ mRNA expression in fertile and infertile groups

Cut off point of fertilin $\beta$ mRNA expression at value of $\leq 1.13$ can distinguish between fertile and infertile groups with specificity 85.5 $\%$, and sensitivity $96.1 \%$, and the area under the curve (AUC) was 0.961. Also Grade A motility can be used as a discriminative marker between fertile and infertile groups at $\leq 24$ with specificity $98.4 \%$, and sensitivity $96.1 \%$, and AUC was 0.991 . Acrosin activity index is another marker at $\leq 5.1$ with specificity $98.4 \%$, and sensitivity $98.7 \%$, and AUC was 0.986. By comparing AUC of fertilin $\beta$ mRNA expression was significantly different from that of acrosin activity index $(p=0.02)$ and grade A motility $(p=0.01)$ while there was insignificant difference of AUC between that of acrosin activity index and grade A motility $(\mathrm{p}=0.13)$. 


\section{DISSCUSSION}

Fertilin $\alpha$ and $\beta$ form a heterodimer and belong to the ADAM family of integral membrane proteins (Menezo, 2006). In fact, ADAM domain-containing protein family, were regulated during epididymal transit and showed changes in the $\mathrm{N}$-linked sialoglycoprotein profile which is a major hallmark of sperm maturation (Villaverde et al., 2016).

The studied infertile samples showed reduced levels of fertilin- $\beta$ mRNA expression compared to the fertile group. These results were consistent with the hypothesis of possible direct role of fertilin- $\beta$ in sperm-egg plasma membrane interaction and fertilization (Sukhikh et al., 2012). Sperm from mice lacking fertilin $\beta$ were shown to be deficient in migration from the uterus into the oviduct, sperm-egg membrane adhesion and fusion and binding to the egg zona pellucida resulting in infertile males (Cho et al., 1998). Furthermore, a monoclonal antibody against fertilin potently inhibits sperm-egg fusion, providing an evidence that fertilin has a critical role in fertilization (Primakoff et al., 1987).

One possible hypothesis that explains decreased fertilin $\beta$ expression is deficiency of inositol polyphosphate 5-phosphatase (Inpp5b) that regulates the levels of 5-phosphorylated phosphoinositides on cellular membranes. It is expressed in the Sertoli cells and epididymis and has been involved in protein trafficking and secretion (De Camilli et al., 1996). Infertility in Inpp5b deficient animals could be explained by improper targeting and/or secretion of the protease that acts on fertilin $\beta$ processing in the epididymal epithelial cells. Incomplete processing of fertilin $\beta$ with defective maturation, translocation or folding of sperm protein resulted in reduced motility and reduced ability to fertilize eggs due to abnormalities in sperm function and maturation (Hellsten et al., 2001). This was in line with the current work results that showed reduced motility of infertile sperms.

Moreover in globozoospermic round headed infertile sperm there is down regulation of cytoskeleton proteins involved in cell movement, signal transduction and membrane shape maintenance as cytoplasmic actin and tubulin- $\alpha-2$ chains (Liao et al., 2009). Actin polymerization and protein tyrosine phosphorylation are related processes occurring in bovine sperm capacitation (Brener et al., 
2003). Actin polymerization is $\mathrm{Ca}^{2+}$-dependent process, as it was almost completely blocked by chelating intracellular $\mathrm{Ca}^{2+}$ (Rivlin et al., 2004).

This could explain the correlation between sperm morphology and fertilin $\beta$ mRNA expression as shown by stepwise regression analysis in the present study. Decreased fertilin $\beta$ mRNA expression that was possibly due to Inpp5 deficiency would decrease levels of 5phosphorylated phosphoinositides and consequently intracellular $\mathrm{Ca}^{2+}$. It has been postulated that the increase in sperm intracellular $\mathrm{Ca}^{2+}$ induce turning swimming with active flagellar bending (Yoshida and Yoshida, 2011). Thus decreased intracellular $\mathrm{Ca}^{2+}$ leads to lack of activation of the mammalian sperm that affects actin polymerization and hence sperm capicitation.

Another theory for association between decreased fertilin $\beta$ and infertility is calmegin abnormality. Calmegin is a $\mathrm{Ca}^{2+}$ binding protein localized on endoplasmic reticulum (ER) membranes acts as a testisspecific molecular chaperone and specifically complexed with both fertilin $\alpha \& \beta$. In calmegin deficient-mice, there was loss of heterodimerization of fertilin $\alpha, \beta$ and fertilin $\beta$ was not detectable in mature sperm. Furthermore, Calmegin is essential for spermatozoa to migrate into oviduct (Cho et al., 2000, Ikawa et al., 2001). Thus Calmegin and fertilin $\beta$ knockout mouse lines share a common infertile phenotype, indicating the importance of calmegin as ER chaperone for sperm membrane protein maturation as well as its importance for spermatozoa migration into oviduct (Bass et al., 1998, Yoshinaga et al., 1999).

ROC curve analysis showed that sperm fertilin $\beta$ mRNA expression, together with acrosin activity index and grade A motility could be used as markers to assess infertility with relatively high specificity and sensitivity. Hormonal changes are believed to be important in sperm production.

This study showed elevated FSH levels together with low testosterone levels that were in agreement with Wei et al. (2013) who reported similar results in patients with oligo-astheno-teratospermia (OAT) which is a common phenotype for infertile men.

In this work, fertilin $\beta$ mRNA expression showed positive correlation with testesterone and negative correlation with FSH. Both correlations satisfied statistical significance. The main role of testosterone action in spermatogenesis is during meiosis and spermiogenesis 
(Ruwanpura et al., 2010). Therefore its adequate supply is crucial for Sertoli cell survival and differentiation in early postnatal life (Sharpe et al., 2003). Testosterone and FSH are considered the major hormonal regulators for male germ cell development at different stages of spermatogenesis by controlling their survival from apoptosis, rather than by stimulating their proliferation (Ruwanpura et al., 2010). Thus, these results of deranged hormonal profile could exert its effect on sperm survival through enhancing extrinsic or intrinsic apoptotic pathways. In conclusion, the present work showed reduced fertilin $\beta$ mRNA expression in infertile men which denotes that fertilin $\beta$ is important to identify the intermolecular relationships among zona binding related proteins and may be necessary to understand the basis of sperm associated fertility. Taken together with the observed hormonal imbalance in the infertile group, this may affect the sperm morphology and motility and hence be a cause of infertility.

\section{REFERENCES}

Bass. J., Chiu. G., Argon. Y., Steiner. D. F. (1998): Folding of insulin receptor monomers is facilitated by the molecular chaperones calnexin and calreticulin and impaired by rapid dimerization. J. Cell Biol, 141: 637-646.

Bigler. D., Takahashi. Y., Chen. M.S., Almeida. E.A., Osbourne. L., White. J.M. (2000): Sequence-specific interaction between the disintegrin domain of mouse ADAM 2 (fertilin beta) and murine eggs. Role of the alpha (6) integrin subunit. J Biol Chem, 275:11576-11584. Brener. E., Rubinstein. S., Cohen. G., Shternall. K., Rivlin. J. \& Breitbart. H. (2003): Remodeling of the actin cytoskeleton during mammalian sperm capacitation and acrosome reaction. Biology of Reproduction, 68:837-845.

Cho. C., Bunch. D.O., Faure. J.E., Goulding. E.H., Eddy. E.M., Primakoff. P., Myles. D.G. (1998): Fertilization defects in sperm from mice lacking fertilin beta. Science, 281(5384):1857-1859.

Cho. C., Ge. H., Branciforte. D., Primakoff. P., Myles. D. G. (2000): Analysis of mouse fertilin in wild-type and fertilin beta (-/-) sperm: Evidence for C-terminal modification, alpha/ beta dimerization, and lack of essential role of fertilin alpha in sperm-egg fusion. Dev. Biol, 222: 289-295. 
Choi. H., Han. C., Jin. S., Kwon. J.T., Kim. J., Jeong. J., Kim. J., Ham. S., Jeon. S., Yoo. Y.J., and Cho. C. (2015): Reduced fertility and altered epididymal and sperm integrity in mice lacking adam7. Biol. Reprod. 93(3):70-73.

De Camilli. P., Emr. S. D., McPherson. P. S., Novick. P. (1996): Phosphoinositides as regulators in membrane traffic. Science, 271: 1533-1539.

Depa-Martynów. M., Kempisty. B., Lianeri. M., Jagodziñski. P., Jêdrzejczak. P.( 2007): Association between fertilin $\beta$, protamines 1 and 2 and spermatid-specific linker histone H1-like protein mRNA levels, fertilization ability of human spermatozoa, and quality of preimplantation embryos. Folia Histochemica Et Cytobiologica,45: Supp. 1, 79-85

Evans. J. P. (1999): Sperm disintegrins, egg integrins and other cell adhesion molecules of mammalian gamete plasma membrane interactions. Front Biosci,4: D114-D131.

Geraci. E., Giudice. G. (2006): Sperm activation and sperm-egg interaction. J Submicrosc Cytol Pathol, 38:11-20.

Guerin. J. F., Ben Ali. H., Rollet. J., Souchier. C., Czuba. J.C. (1986): Alpha-glucosidse as a specihie eqididymal enzime markers its validity for the etiologie diagnosis of azoopermia. J Androl, 1: 156 162

Hellsten. E., Evans. J.P., Bernard. D.J., Janne. P.A., Nussbaum. R.L. (2001): Disrupted Sperm Function and Fertilin b Processing in Mice Deficient in the Inositol Polyphosphate 5-Phosphatase Inpp5b. Developmental Biology,240: 641-653

Henkel. R., Muller. C., Miska. W., Schill. W.B., Kleinstein. J., Gips. H. (1995): Acrosin activity of human spermatozoa by means of a simple gelatinolytic technique: a method useful for IVF. J Androl,16: 272-7.

Hinting. A., Comhaire. F., Schoonjans. F. (1998): Capacity of objectively assessed sperm motility characteristics in differentiating between semen of fertile and subfertile men. Fertil Steril, 50 (4):6359.

Howes. E., Pascall. J.C., Engel. W., Jones. R. (2001): Interactions between mouse ZP2 glycoprotein and proacrosin; a mechanism for secondary binding of sperm to the zona pellucida during fertilization. J Cell Sci, 114:4127-36. 
Ikawa. M., Nakanishi. T., Yamada. S., Wada. I., Kominami. K., Tanaka. H., Nozaki. M., Nishimune. Y., Okabe. M. (2001): Calmegin is required for fertilin alpha/beta heterodimerization and sperm fertility. Dev Biol, 240:254-261.

Ikawa. M., Wada. I., Kominami. K., Watanabe. D., Toshimori. K., Nishimune. Y., Okabe. M. (1997): The putative chaperone calmegin is required for sperm fertility. Nature, 387: 607-611.

Liao. T. T., Xiang. Z., Zhu. W. B., Fan. L. Q. (2009): Proteome analysis of round-headed and normal spermatozoa by 2-D fluorescence difference gel electrophoresis and mass spectrometry. Asian J Androl.,11:683-93

Menezo. Y.J. (2006): Paternal and maternal factors in preimplantation embryogenesis: interaction with the biochemical environment. Reprod Biomed Online, 12:616-621.

Primakoff. P., Hyatt. H., Tredick-Kline. J. (1987): Identification and purification of a sperm surface protein with a potential role in sperm-egg membrane fusion. J Cell Biol, 104:141-149.

Primakoff. P., Myles. D. G. (2000): The ADAM gene family: surface proteins with adhesion and protease activity. Trends Genet, 16:83-87.

Rivlin. J., Mendel. J., Rubinstein. S., Etkovitz. N., Breitbart. H. (2004): Role of hydrogen peroxide in sperm capacitation and acrosome reaction. Biology of Reproduction, 70: 518-522.

Ruwanpura. S.M., McLachlan. R.I., Meachem. S.J. (2010): Hormonal regulation of male germ cell development. J Endocrinol, 205:117e31.

Schoonjans. F., Zalata. A., Depyudt. C. E. , Comhaire. F. H. (1995): MedCalc: a new computer program for medical statistics . Computer Methods and Programs in Biomedicine, 48: 257-262.

Sharpe. R.M., McKinnell. C., Kivlin. C., Fisher. J.S. (2003): Proliferation and functional maturation of Sertoli cells, and their relevance to disorders of testis function in adulthood. Reproduction, 125:769-84.

Sukhikh. G.T., Bourmenskaya. O.V., Smolnikova. V.Y., Krasnoschoka. O.E., Trofimov. D.Y., Donnikov. A.E., Kalinina. E.A. (2012): Protamine and fertilin mRNA. Potential biomarkers of assisted reproductive technology outcomes. Bull Exp Biol Med, 153(4):513-5. 
Vieira. A., Miller. D.J. (2006): Gamete interaction: is it speciesspecific? Mol Reprod Dev, 73:1422-9.

Villaverde. A.I., Hetherington. L., Baker. M.A. (2016): Quantitative Glycopeptide Changes in Rat Sperm During Epididymal Transit. Biol. Reprod, 94(4):91-95

Wei. T., Huang. W.J., Lin. A., Chen. K. (2013): The role of hormones on semen parameters in patients with idiopathic or varicocele-related oligoastheno-teratozoospermia (OAT) syndrome. Journal of the Chinese Medical Association,76: 624-628.

Wolkowicz. M.J., Digilio. L., Klotz. K., Shetty. J., Flickinger. C.J., Herr. J.C. (2008): Equatorial segment protein (ESP) is a human alloantigen involved in sperm-egg binding and fusion. J Androl, 29:272-282.

World Health Organization (2010): WHO laboratory manual for the Examination and processing of human semen, 5th Edition, 20 Avenue Appia, 1211 Geneva 27, Switzerland.

Yang. Y., Hui. H., Zhang. D., Ren. H. (2007): Identification of proteins responsible for development of Adriamycin resistance in human cancer gastric cells using comparative proteomics analysis. Journal of biochemistry and molecular biology, 40(6): 853-860.

Yoshida. M. \& Yoshida. K. (2011): Sperm chemotaxis and regulation of flagellar movement by $\mathrm{Ca} 2+$. Molecular Human Reproduction, 17: 457-465.

Yoshinaga. K., Tanii. I., Toshimori. K. (1999): Molecular chaperone calmegin localization to the endoplasmic reticulum of meiotic and post-meiotic germ cells in the mouse testis. Arch Histol Cytol, 62: 283-293. 


$$
\text { الملخص العربى }
$$

العلاقة بين التعبيرالجينى للحمض النووى الريبوزى للقرتيلين بيتا والقدرة الاخصابية للحيوانات المنوية الريون

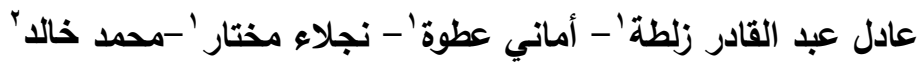

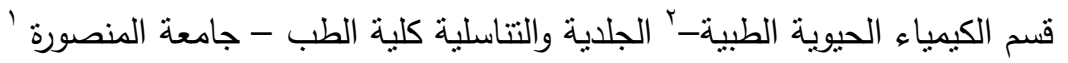

الفرتيلين بيتا هو بروتين يوجد على سطح الحيوان المنوي و ينتمي إلى عائلة البروتينات

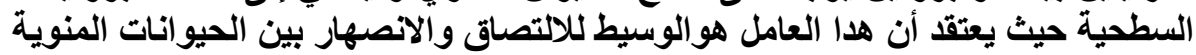

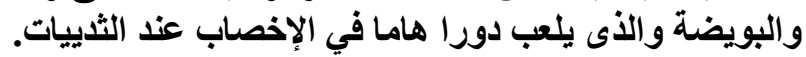

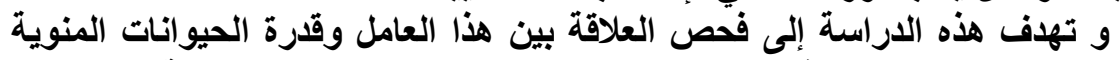

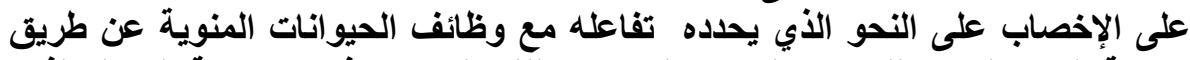

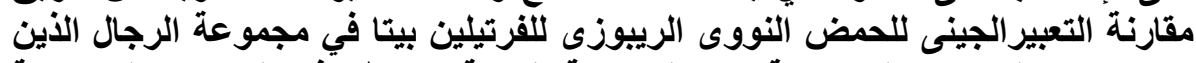

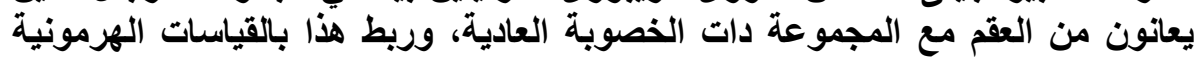

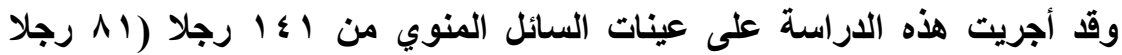

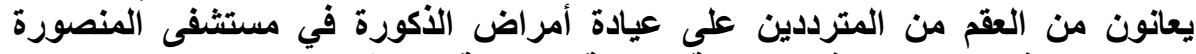

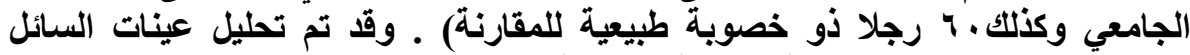

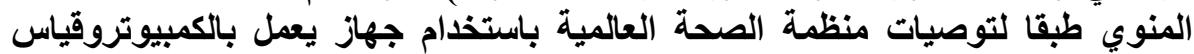

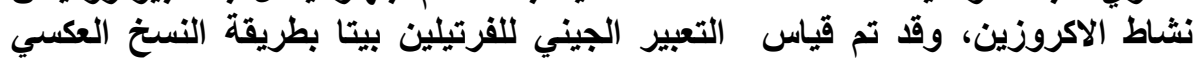

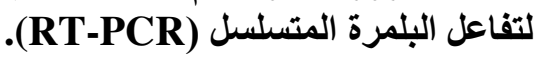
وقد تم قياس هرمون LH ، FSH،وهرمون التستوستيرون وهرمون البرولاكتين

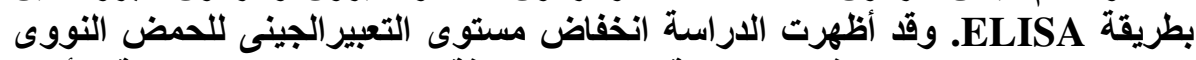

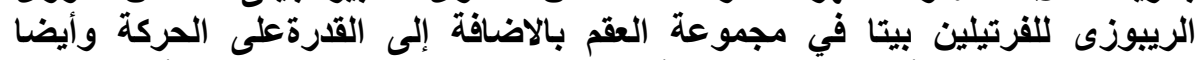

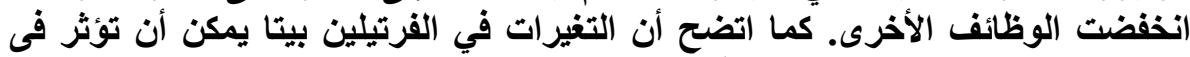

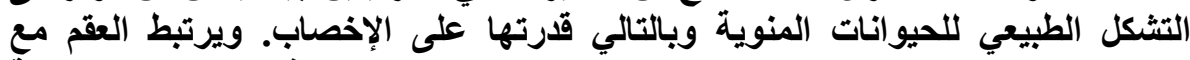

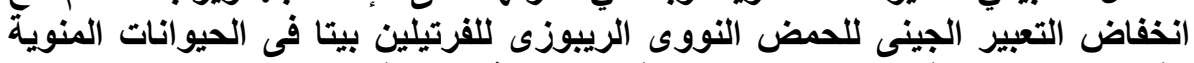

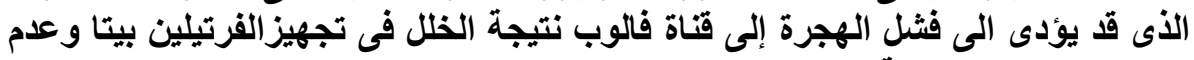
نضج الحيوانات المنوية. 